\title{
Juxtaposing Types of Family-Work Conflict Between Malaysian and Western Employees
}

\author{
Zaiton Hassan, Nur Fatihah Abdullah Bandar, Suren Sabil, Dayang Kartini Abang Ibrahim, Nik \\ Norsyamimi Md Nor
}

\begin{abstract}
In comparison to work-family conflict (WFC), family-work conflict (FWC) has not been examined heavily, particularly the types of family-work conflict, that is., time-based, strain-based and behaviour-based. Even though many antecedents for FWC originated from family domain, due to spillover and crossover effect, organization will also suffer the negative consequences of FWC. Thus, by understanding the specific types of the family-work conflict, more specific interventions can be undertaken by organizations. The aim of this study is to advance the understanding of family-work conflict types in Eastern culture by comparing it with ten Western studies that utilized the same measure i.e. family-work conflict scale by Carlson, Kacmar and William [1]. Descriptive statistics and one sample t test in SPSS version 23 were used to analyze the data. In general, behaviour-based FWC is higher than time and strain-based FWC. Malaysian employees scored significantly higher FWC than did other Western studies. Male Malaysian respondents particularly, scored highest in all three dimensions of FWC than did the Westerners. Thus, culture dimensions such as collectivist and polychronic time orientation as well as support for child and elder care and social problems may shed some lights on understanding this interesting finding.
\end{abstract}

Keywords: Family-work conflict, Time-based, Strain-based, Behavior-based, Malaysia

\section{INTRODUCTION}

$\mathrm{W}$ ork life balance (WLB) view as a lack of conflict or interference between work and family roles, that is, low levels of inter role conflict (negative interaction between work and family) and high level of inter role facilitation (positive interaction of work and family [2]. This definition has been used to categorize WLB into negative and positive interaction between work and family. The negative interaction between work and family interface is also known as work-family conflict, work interference with family and negative spill over. Work-family conflict remains a key

Revised Manuscript Received on October15, 2019

* Correspondence Author

Zaiton Hassan*, Faculty of Cognitive Sciences and Human Development, Universiti Malaysia Sarawak, Kota Samarahan, Sarawak, Malaysia. (Email: hzaiton@unimas.my)

Nur Fatihah Abdullah Bandar, *, Faculty of Cognitive Sciences and Human Development, Universiti Malaysia Sarawak, Kota Samarahan, Sarawak, Malaysia.

Suren Sabil, *, Faculty of Cognitive Sciences and Human Development Universiti Malaysia Sarawak, Kota Samarahan, Sarawak, Malaysia.

Dayang Kartini Abang Ibrahim, *, Faculty of Cognitive Sciences and Human Development, Universiti Malaysia Sarawak, Kota Samarahan, Sarawak, Malaysia.

Nik Norsyamimi Md Nor, *, Faculty of Cognitive Sciences and Human Development, Universiti Malaysia Sarawak, Kota Samarahan, Sarawak, Malaysia. factor for many employees, a challenge with current research is that scholars often methodologically and theoretically confound all forms of non-work conflict in the work-family measure [3].

The most quoted definition of WFC is by Greenhaus and Beutell which was defined Work Family Conflict as:

A form of inter role conflict, in which the demands of work and family roles are incompatible in some respect, so that participation in one role is more difficult because of participation in the other's role [4, p. 77].

This conflict is bidirectional, that is, work can interfere with family matters (Work Family Conflict - WFC) and also family can interfere with work (Family Work Conflict FWC). Greenhaus and Beutell [4] further divided this conflict into three (3) types, which are: time-based (time pressure, lack of time for family, leisure etc.), strain-based (anxiety, fatigue, tension) and behaviour-based (incompatible behavioural expectations between work and home life) Carlson, Kacmar and William [1] further developed the three types of WFC and FWC into 18 items scale which has been used to measure work family conflict (WFC) and family work conflict (FWC) globally including Malaysia (see [5], [6]).

In comparison to work-family conflict (WFC), family-work conflict (FWC) has not been examined heavily, particularly the three types of family-work conflict, time-based, strain-based and behaviour-based. Even though many antecedents for FWC originated from family domain, due to spillover and crossover effect, organization will also suffer the negative consequences of FWC. Thus, by understanding the specific types of the family-work conflict, more specific interventions can be undertaken by organizations.

Kelloway, Gottieb and Barham [7] in their six-month longitudinal survey data suggested that strain-based FWC is an antecedents to stress and turnover intentions. Strain-based emerged as an outcome of stress. Time-based usually related to household chores and caring activity for children and / or elderly. Therefore, number of children, age of the youngest child, and family size (including older relatives) are the possible antecedents of time-based conflict. Strain-based include lack of spousal support, husband-wife dissimilarity in career orientation, in family roles, and in attitudes towards a wife's employment status. Behaviour-based include family-role ambiguity, intra-family role conflict, and high family role involvement [8]. Thus, the aim of this study is to advance the understanding of family-work conflict types in Eastern culture by comparing it with ten Western studies that utilized the same measure i.e.

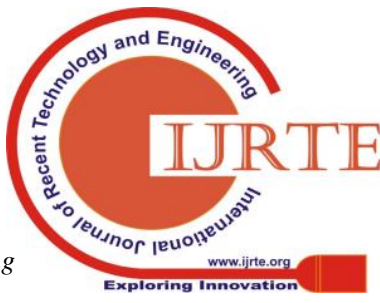


family-work conflict scale by Carlson, kacmar and William [1].

\section{METHODOLOGY/MATERIALS}

Western studies were found by using database such as Science Direct and Business Source Complete. Keywords entered were "family-work conflict measure" and "Carlson". A total of ten articles were found, and one article, Lapierre et al. [8] reported mean score of WFC and FWC for five countries. A total of 10 studies were utilised to compare with a Malaysian study. Four studies represented the United States [1], [8] [10], [11], [13], two from Australia and New Zealand [8], [16], and one from Canada [8], and Finland [8]. Data on Malaysian study was collected from 506 respondents in three public and private sector in Sarawak, Malaysia.

Family-Work Conflict was assessed with an instrument developed by Carlson, Kacmar and Williams [1]. Total of 9 items with 3 questions for each dimension of conflict i.e. time-based, strain-based and behavior-based. It is scored on a 5 -point scale $(1=$ strongly disagree, $5=$ strongly agree $)$. The items are averaged, and higher scores indicating more family-work conflict.

\section{RESULTS AND FINDINGS}

Table 1 presents mean, standard deviation, and one sample t-test results of Malaysian and 10 Western studies. Only two western studies reported multi dimensionality of FWC based on gender (Study 2 and Study 3). As in Table 1, the overall mean of FWC, Malaysian employees scored 2.55 and Western employees scored in between 1.90 to 2.35 , meaning Malaysians scored the highest. In short, a coherent trend across the culture emerge, i.e., behaviour-based FWC is higher than time and strain-based FWC. Malaysian employees scored higher FWC than did other Western studies. Male Malaysian respondents particularly, scored highest in all three dimensions of FWC than did the Westerns. Culture dimensions of Malaysia such as collectivist, polychronic time orientation, traditional gender role ideology as well as current social problems may shed some lights on understanding this interesting finding.

\section{DISCUSSION}

Firstly, in Asian culture, which is usually characterized by polychronic time orientation (doing multiple tasks at one time), work and family boundary is less clear cut, rather work and social life are interweave [21]. In contrast, boundary between work and non-work (family and leisure) in the Western culture is distinct [21]. Because of the elasticity of the work and family boundary, employee feel comfortable to address family issues at the workplace. For instance, Hassan , Dollard and Winefield [5] reported that all six organisations in their study give access to family calls. Therefore, as workplace is viewed as a safe haven to raise family issues, coupled with paternalistic nature of the organization [22], employees feel secure to bring up family issues at work, which may then, resulted in higher score in report of FWC compared to western studies.

Secondly, Malaysia is a collectivist community and, thus a relationship-oriented. As family is the most important in-group for collectivist [23], whatever happen in / to the family affects the individual. Moreover, family, for collectivist, is not only the immediate, but include the extended - aunties, uncles, cousins, in-laws, nephews etc, As the number of member of the in-group is big, many more family issues may occur, more visits to family and more functions to attend, which can be time and energy consuming , which, in turn, may contribute to FWC. For collectivist, personal happiness comes second [23]. Thus, caring for family and friends is identified as the most important social aspect that affecting women's occupational health in Malaysia [24] which may lead to strain-based FWC.

Thirdly, as Malaysia progress economically, social problems such as drugs abuse, robbery, juvenile, divorce, traffic accidents are also in the rise [25]. For instance, there is a 332 percent increase in traffic accidents in Sarawak from 1990 to 2000) [25]. Juvenile crime rate increased from 0.51 percent in 1990 to 0.65 in 2002 [26]. Divorce rate among Muslims in Sarawak increase 25.9\% from 3,995 cases (1997) to 5,393 cases (2007), which is comparable to the country's divorce rate. A recent data provided by the Department of Statistics Malaysia [27], the criminal index ratio per 100,000 population recorded is 230.7 and 440 cases of drug addicts in Sarawak [28]. In addition to this, although the same phenomenon occurs in western developed country, the stress for family in collectivist society is more profound. The stress is due to group-oriented nature of the society. When a family member is involved in social problems the whole family will lose 'face' or feel ashamed. The family is seen as violating the group norms. Therefore, the group will talk bad or reject them, or the family themselves perceived other people are talking bad about them, thus distancing themselves from the group. Either way it is a stressful experience, which cause strain-based FWC.

Fourthly, in line with economic growth in Malaysia, percentage of women in labour force participation has also intensified (53.7\% 2014 to 55.7\% in 2018) [27], [29]. Having a dual earner families are quite common in Malaysian. Thus, higher behaviour-based FWC for Malaysian male employees, can be explained by a gradual change of gender role ideology which currently emerging in Malaysia. According to a collectivist view, men are seen as the leader in the family and his primary role as the breadwinner plays a significant financial provider in the family. A new paradigm shift in Malaysia is urging men to be more participative in the hometo assist in household chores and childcare through popular media, motivational talk, parenting seminars and courses [26]. Getting into the household activities and child care required new skills and attitude. This is a challenging task because men have no role model to emulate. Older generation of men and women has strongly believed in strict division of labour between a task of men and women. In olden days, society disapproved men who helped around the house and if they do, they will be perceived as 'weak' and 'being controlled' by the wife. Thus, crossing over from work to family boundary and vice versa is difficult for younger generation of menfolk, which may lead to behaviour- based FWC. 


\section{CONCLUSION}

Although antecedents of FWC may originate from the family domain, due to spillover and crossover effect, organizations may suffer the consequences. Thus, it suggested for organizations to provide family friendly policies initiatives such as childcare services, scholarship for excellent employee's children, family supportive culture to assist employees.

In sum, this study presents preliminary evidence that types of family-work conflict in Malaysia, an Asian country with Eastern culture, is experienced in different ways from the
Western culture. In general, Malaysians employees significantly experienced more time-based, strain-based, and behavior-based FWC compared to Western employees. Cultural dimensions of Malaysians such collectivist, polychronic time orientation, traditional gender role ideology may be the reasons for these findings. Thus, it is important for organizations to assist the family domain of the employees, so that employees can be effective and efficient parents and children too.

Table 1: Malaysian and Western studies on the multidimensional perspective of FWC

\begin{tabular}{|c|c|c|c|c|c|c|c|c|c|c|c|c|c|c|c|c|c|c|c|}
\hline & & & \multicolumn{5}{|c|}{ Time-Based } & \multicolumn{5}{|c|}{ Strain-Based } & \multicolumn{5}{|c|}{ Behaviour-Based } & \multirow{3}{*}{$M$} & \multirow{3}{*}{ SD } \\
\hline & & & & $M$ & $S$ & $D$ & $t$ & & $M$ & $S$ & $D$ & $t$ & & $M$ & $S$ & $D$ & $t$ & & \\
\hline \multicolumn{3}{|c|}{ Author (Year) Sample } & $\mathrm{M}$ & $\mathrm{F}$ & $\mathrm{M}$ & $\mathrm{F}$ & & $\mathrm{M}$ & $\mathrm{F}$ & $\mathrm{M}$ & $\mathrm{F}$ & & $\mathrm{M}$ & $\mathrm{F}$ & $\mathrm{M}$ & $\mathrm{F}$ & & & \\
\hline 1. & $\begin{array}{c}\text { Hassan } \\
{[22],} \\
\text { Malaysia }\end{array}$ & $\begin{array}{l}506 \text { public } \\
\text { and private } \\
\text { sectors }\end{array}$ & $\begin{array}{c}2.5 \\
7\end{array}$ & 2.43 & .71 & .69 & - & 2.40 & 2.30 & .75 & .72 & - & 2.90 & 2.68 & .65 & .67 & - & 2.55 & .57 \\
\hline 2. & $\begin{array}{c}\text { Carlson, } \\
\text { Kacmar } \\
\text { and } \\
\text { William } \\
\text { [1], USA }\end{array}$ & $\begin{array}{l}222 \text { full-time } \\
\text { employees. } \\
83 \text { male } 139 \\
\text { female }\end{array}$ & $\begin{array}{c}1.7 \\
7\end{array}$ & 2.01 & NA & NA & $\begin{array}{c}18.46(\mathrm{M}) \\
8.44(\mathrm{~F})\end{array}$ & 1.71 & 1.93 & NA & NA & $\begin{array}{c}14.83(\mathrm{M}) \\
7.33(\mathrm{~F})\end{array}$ & 2.36 & 2.65 & NA & NA & $\begin{array}{c}13.28 \\
(\mathrm{M}) \\
.76 \mathrm{~ns} \\
(\mathrm{~F})\end{array}$ & 2.07 & NA \\
\hline 3. & $\begin{array}{c}\text { Herst [16] } \\
\text { Australia } \\
\text { and New } \\
\text { Zealand }\end{array}$ & $\begin{array}{l}392 \text { full-time } \\
\text { employees }\end{array}$ & $\begin{array}{c}2.1 \\
4\end{array}$ & 1.94 & 0.99 & 0.91 & $\begin{array}{l}9.95(\mathrm{M}) \\
9.86(\mathrm{~F})\end{array}$ & 1.64 & 1.60 & 0.80 & 0.77 & $\begin{array}{l}16.34(\mathrm{M}) \\
13.78(\mathrm{~F})\end{array}$ & 2.54 & 2.59 & 1.04 & 1.04 & $\begin{array}{c}8.83 \\
(\mathrm{M}) \\
2.03(\mathrm{~F})\end{array}$ & 2.07 & NA \\
\hline 4. & $\begin{array}{c}\text { Carlson, } \\
\text { Derr, and } \\
\text { Wadswort } \\
\text { h [11], } \\
\text { USA } \\
\end{array}$ & $\begin{array}{c}247 \\
\text { Executives }\end{array}$ & & 1.99 & 0. & & 16.02 & & .82 & 0 . & 77 & 15.73 & & 2.53 & 0. & 80 & 8.73 & 2.11 & NA \\
\hline 5. & $\begin{array}{c}\text { Rotondo, } \\
\text { Carlson, } \\
\text { and } \\
\text { Kincaid } \\
{[13], \text { USA }} \\
\end{array}$ & $\begin{array}{c}173 \\
\text { employees }\end{array}$ & & 1.94 & 0. & & 17.55 & & .87 & 0. & 80 & 14.27 & & NA & $\mathrm{N}$ & A & NA & 1.90 & NA \\
\hline 6 & $\begin{array}{c}\text { Lapierre et } \\
\text { al. [8], } \\
\text { Australia }\end{array}$ & $\begin{array}{l}\text { Business } \\
\text { school's } \\
\text { alumni }\end{array}$ & & 2.31 & 0. & & 6.21 & & .06 & 0. & 81 & 8.72 & & 2.62 & 0. & 82 & 5.81 & 2.33 & NA \\
\hline 7 & $\begin{array}{c}\text { Lapierre et } \\
\text { al.[8], } \\
\text { Canada }\end{array}$ & $\begin{array}{l}\text { Business } \\
\text { school's } \\
\text { alumni }\end{array}$ & & 2.31 & 0. & & 6.21 & & .06 & & 81 & 8.72 & & 2.62 & 0. & 82 & 5.81 & 2.35 & NA \\
\hline 8 & $\begin{array}{c}\text { Lapierre } e t \\
\text { al. [8], } \\
\text { New } \\
\text { Zealand }\end{array}$ & $\begin{array}{l}\text { Business } \\
\text { school's } \\
\text { alumni }\end{array}$ & & 2.35 & 0. & & 4.99 & & .96 & & 71 & 11.64 & & 2.58 & 0. & 81 & 7.11 & 2.30 & NA \\
\hline 9 & $\begin{array}{c}\text { Lapierre et } \\
\text { al. [8], } \\
\text { USA }\end{array}$ & $\begin{array}{l}\text { Business } \\
\text { school's } \\
\text { alumni }\end{array}$ & & 2.35 & 0. & & 4.99 & & .96 & & 71 & 11.64 & & 2.58 & 0. & 81 & 7.11 & 2.43 & NA \\
\hline 10 & $\begin{array}{c}\text { Lapierre et } \\
\text { al. [8], } \\
\text { Finland }\end{array}$ & $\begin{array}{l}\text { Business } \\
\text { school's } \\
\text { alumni }\end{array}$ & & 2.25 & 0. & & 8.05 & & .83 & & 72 & 15.44 & & 2.75 & 0. & 78 & $1.60 \mathrm{~ns}$ & 2.27 & NA \\
\hline 11 & $\begin{array}{l}\text { Bruck et } \\
\text { al. }[10], \\
\text { USA }\end{array}$ & $\begin{array}{l}160 \text { married } \\
\text { hospital } \\
\text { employees }\end{array}$ & & 2.27 & 0. & & 7.44 & & .09 & & 79 & 7.84 & & 2.62 & 0. & 84 & 5.82 & 2.33 & 0.59 \\
\hline
\end{tabular}




\section{REFERENCES}

1. D. S. Carlson, K. M. Kacmar, and L. J. Williams, "Construction and initial validation of a multidimensional measure of work-family conflict," J. Vocat. Behav., vol. 56, no. 2, pp. 249-276, Apr. 2000.

2. M. R. Frone, "Work-family conflict and employee psychiatric disorders: The national comorbidity survey.," J. Appl. Psychol., vol. 85, no. 6, pp. 888-895, 2000.

3. K. S. Wilson and H. M. Baumann, "Capturing a more complete view of employees' lives outside of work: The introduction and developmen of new interrole conflict constructs," Pers. Psychol., vol. 68, no. 2, pp. 235-282, Jun. 2015.

4. J. H. Greenhaus and N. J. Beutell, "Sources of conflict between work and family roles," Acad. Manag. Rev., vol. 10, no. 1, p. 76, Jan. 1985.

5. Z. Hassan, M. F. Dollard, and A. H. Winefield, "Work-family policy and work-family conflict in the Malaysian private sector: A preliminary study," in 7th Industrial and Organisational Psychology/lst Asia Pacific Congress on Work and Organisational Psychology, 2007.

6. S. Marican and S. Sabil, "Participation and challenge of women in the workplace," in Human Capital Transformation: 55 Years of Malaysian Experience, Putrajaya: Ministry of Human Resources, 2012, pp. 221-248.

7. E. K. Kelloway, B. H. Gottlieb, and L. Barham, "The source, nature, and direction of work and family conflict: A longitudinal investigation.," J. Occup. Health Psychol., vol. 4, no. 4, pp. 337-346, 1999.

8. L. M. Lapierre et al., "Family-supportive organization perceptions, multiple dimensions of work-family conflict, and employee satisfaction: A test of model across five samples," J. Vocat. Behav., vol. 73, no. 1, pp. 92-106, Aug. 2008.

9. S. L. Boyar, C. P. Maertz, and A. W. Pearson, "The effects of work-family conflict and family-work conflict on nonattendance behaviors," J. Bus. Res., vol. 58, no. 7, pp. 919-925, Jul. 2005.

10. C. S. Bruck, T. D. Allen, and P. E. Spector, "The Relation between Work-Family Conflict and Job Satisfaction: A Finer-Grained Analysis," J. Vocat. Behav., vol. 60, no. 3, pp. 336-353, Jun. 2002.

11. D. S. Carlson, C. B. Derr, and L. L. Wadsworth, "The effects of internal career orientation on multiple dimensions of work-family conflict," J. Fam. Econ. Issues, vol. 24, no. 1, pp. 99-116, 2003.

12. T. D. Golden, J. F. Veiga, and Z. Simsek, "Telecommuting's differential impact on work-family conflict: Is there no place like home?," J. Appl. Psychol., vol. 91, no. 6, pp. 1340-1350, 2006.

13. D. M. Rotondo, D. S. Carlson, and J. F. Kincaid, "Coping with multiple dimensions of work-family conflict," Pers. Rev., vol. 32, no. 3, pp. 275-296, Jun. 2003.

14. K. M. Shockley and T. D. Allen, "When flexibility helps: Another look at the availability of flexible work arrangements and work-family conflict," J. Vocat. Behav., vol. 71, no. 3, pp. 479-493, Dec. 2007

15. L. A. Witt and D. S. Carlson, "The work-family interface and job performance: Moderating effects of conscientiousness and perceived organizational support.," J. Occup. Health Psychol., vol. 11, no. 4, pp. 343-357, 2006.

16. D. E. L. Herst, "Cross-cultural measurement invariance of work/family conflict scales acorss English-speaking samples," University of South Flordia, 2003.

17. D. S. Carlson, K. M. Kacmar, and L. J. Williams, "Construction and initial validation of a multidimensional measure of work-family conflict," J. Vocat. Behav., vol. 56, no. 2, pp. 249-276, Apr. 2000.

18. C. S. Bruck, T. D. Allen, and P. E. Spector, "The Relation between work-family conflict and job satisfaction: A finer-grained analysis," $J$. Vocat. Behav., vol. 60, no. 3, pp. 336-353, Jun. 2002.

19. S. L. Boyar and D. C. Mosley, "The relationship between core self-evaluations and work and family satisfaction: The mediating role of work-family conflict and facilitation," J. Vocat. Behav., vol. 71, no. 2, pp. 265-281, Oct. 2007.

20. L. A. Witt and D. S. Carlson, "The work-family interface and job performance: Moderating effects of conscientiousness and perceived organizational support," J. Occup. Health Psychol., vol. 11, no. 4, pp. 343-357, 2006.

21. L. A. Manrai and A. K. Manrai, "Effects of cultural-context, gender, and acculturation on perceptions of work versus social/leisure time usage," J. Bus. Res., vol. 32, no. 2, pp. 115-128, Feb. 1995.

22. Z. Hassan, M. F. Dollard, and A. H. Winefield, "Work-family conflict in East vs Western countries," Cross Cult. Manag. An Int. J., vol. 17, no. 1, pp. 30-49, Feb. 2010.

23. G. Hofstede, Cultures and organizations: Software of the mind. London: McGraw-Hill, 1991.

24. B. Choi, “An international comparison of women's health issues in the
Philippines, Thailand, Malaysia, Canada, Hong Kong, and Singapore: The CIDA-SEAGEP study," Sci. World J., vol. 4, pp. 989-1006, 2004 25. R. M. Amin, S. A. Yusof, and M. A. M. Haneef, "Values, social problems and balanced development in Malaysia," J. Socio. Econ., vol. 35, no. 1, pp. 151-163, Feb. 2006.

26. Economic Planing Unit, "Malaysian qualiy of life," Putrajaya, 2004.

27. Department of Statistics Malaysia, "Labour force survey report, Malaysia, 2018," Putrajaya, 2018.

28. U. M. Mohammad, "Crime statistics, Malaysia, 2018," Putrajaya, 2018.

29. Department of Statistics Malaysia, "Labour force survey report, Malaysia, 2018," Putrajaya, 2016.

\section{AUTHORS PROFILE}

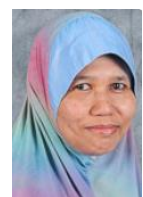

Dr. Zaiton Hassan is an Associate Professor of Human Resource Development Program, Faculty of Cognitive Sciences and Human Development, Universiti Malaysia Sarawak, Malaysia. She received her PhD (Organizational Psychology) from University of South Australia, Adelaide, Australia in 2010, Master of Science (Organizationa Psychology) from University of Hertfordshire, United Kingdom and bachelor's degree in human development from Universiti Putra Malaysia. Her PhD thesis Work-Life Balance among Malaysian Employees had been selected for inclusion in the overall compendium of activities for the World Health Organization (WHO) Global Plan of Action 2008-2012 for UniSA WHO collaborating center for occupational health. She has published more than 30 papers (indexed and non-indexed) in the area of Work Life Balance as well as other human resources related topic. She is an editor for one book on Contemporary Research on Work Life Balance in Malaysia (2016) published by Universiti Malaysia Sarawak Press and contributed book chapters in psychosocial factors at work published by Springer (2014). She served as reviewer for indexed journals in human resource, managemen related field and had won a few Best Paper Award at national and international conferences. Her current research interests include work-life balance, religiosity, flow at work and voice and silence. Recent consultancy project includes establishment of childcare center at workplace (2017-2020), organizational culture (2017-2020) and change (2019-2020) in private and public sector in Sarawak, Malaysia.

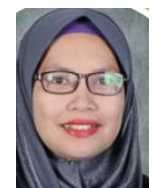

Dr. Nur Fatihah Abdullah Bandar is a Senior Lecturer at Human Resource Development Programme in the Faculty of Cognitive Sciences and Human Development, Universiti Malaysia Sarawak. She was a Research Assistant at Asia -Europe Institute, Universiti Malaya (2010-2013) before joining the Universiti Malaysia Sarawak in 2014. She graduated with a Bachelor of Science in (Human Development) in 2006 and Master degree in Human Resource Development from Universiti Putra Malaysia in 2010 and her doctorate (PhD) in Social Sciences and Humanities (Quality of Life) from Universiti Malaya in 2015. For the most part of her career, her research is geared towards quality of life, quality of work life, career development, disability studies, happiness studies and well-being. She won a few Best Paper Award and Best Presenter Award at conferences and actively publish in indexed and non-indexed publication. Since 2014, her teaching portfolio are statistics for Social Sciences for postgraduate students, and work-life balance, career development, Introduction to Human Resource Development and Human Development Psychology, Organizational Development for undergraduate level. She also involved in MOOC development for Introduction to Human Resource Development. She has been invited to become a trainer for SPSS Workshop for (Basic and Intermediate) level for postgraduate students and also for the general public.

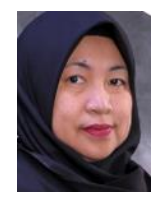

Dr. Surena Sabil is currently a Senior Lecturer at Department of Human Resource Department, Faculty of Cognitive Sciences and Human Development, Universiti Malaysia Sarawak (UNIMAS). She was conferred Doctor of

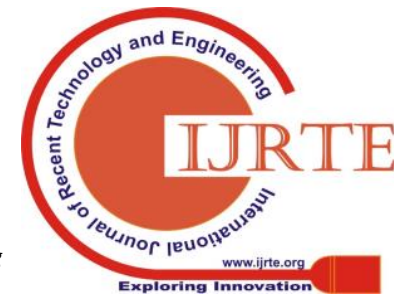


Philosophy (Public Management) by University of Malaya in 2013, Master of Business in Quality Management from University of Western Sydney in 2002 and Bachelor Science in Human Development from Universiti Putra Malaysia in 1997. Currently she is the Dean of Faculty of Cognitive Sciences and Human Development, Universiti Malaysia Sarawak. To date she has published more than 20 articles in local and international journals and conference proceedings related to her area as well as supervise $\mathrm{PhD}$ and Master by research students. Her current research interest is on work-family balance/career development, women development and quality management. She is also involved in consultancy projects for public and private sector in Sarawak, Malaysia

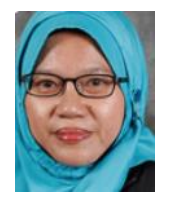

Dayang Kartini binti Abang Ibrahim received her Bachelor of Education in TESL at University of Exeter, United Kingdom in 1999. She started her Master degree in the field of Human Resource Development and graduated in 2007. She started working in Ministry of Education as a teacher from 1999 until 2004. In 2005, she worked in Kuching District Education office as the language officer. She resigned from Ministry of Education and started to work in University Malaysia Sarawak in 2010. Currently, she is pursuing her study in Phd at UPM in the field of Human Resource Development. Most of her research and publications are related to the area of education, work-life balance and retirement planning and preparation in organization.

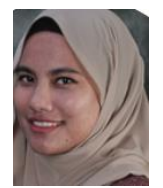

Nik Norsyamimi binti Md Nor is currently hold a position as a University Lecturer in University Malaysia Sarawak (UNIMAS). She attended the University Utara Malaysia (UUM) for her Bachelor of Science in Human Resource Management and Mater of Science in Management in year of 2006. Before her tenure in education field, she has been served as a research assistant in UUM and a human resource practitioner in financial private company for several years. She also has collaborated with other Faculty members in writing project work and book write up in the area of work life balance, organizational behavior, and soft skills development and currently towards the Labor Studies. Based on her research interest background, her passion is to explore in depth on the turnover/ turnover intention issues in Malaysia perspective. Most of research papers published in several conferences/journals was emphasized on turnover and work life balance. Some of the research works was in National Research Grant (Research Acculturation Collaborative Effort-RACE), Internal Research Grant (Short Grant Scheme-SGS) and Fundamental Research Grant Scheme (FRGS). 